УДК 621.87
DOI 10.36910/6775-2313-5352-2020-17-7
Драган А.П.
ВП НУБіП України «Бережанський агротехнічний інститут»

\title{
ТЕХНОЛОГІЧНЕ СПОРЯДЖЕННЯ ДЛЯ НАВИВАННЯ ГВИНТОВИХ ГОФРОВАНИХ ЗАГОТОВОК З ЗАДАНИМ ПРОФІЛЕМ
}

В даній статті наведено зразки технологічного оснащення для виготовлення гвинтових гофрованих заготовок з заданим профілем гофр. зокрема пристрій для виготовлення гофрованих гвинтових заготовок изиліндричними формуючими елементами $і$ пристрій для виготовлення гофрованих гвинтових заготовок конічними формуючими елементами. Розглянуто теоретичні основи прочесу формоутворення гофрованих гвинтових заготовок Визначено зусилля, яке необхідне для гнуття заготовки у вигляді стрічки між двома прямозубими колесами, косозубими колесами, та колесами спеціального профілю. На основі отриманих рівнянь побудовано графіки залежності сили гофроутворення від ширини стрічки.

Ключові слова: гвинтова гофрована заготовка, зусилля формоутворення.

Вступ. Гвинтові гофровані заготовки набули широкого застосування у змішувачах, теплообмінниках, машинах для борботації, подрібнення, зволоження та ін. Підвищені вимоги до конструктивних і технологічних параметрів, якості, надійності та довговічності, розширення функціональних можливостей гвинтових гофрованих заготовок потребують глибокого аналізу існуючих технологій їх виготовлення та здійснення на цій основі науково обгрунтованих теоретичних та експериментальних напрацювань 3 метою успішного їх впровадження у виробництво.

Постановка проблеми. Незважаючи на значну кількість наукових праць, які присвячені виробництву гвинтових гофрованих заготовок, рівень технологічного забезпечення в нашій державі та за ії межами залишається недостатньо високим, а науково база для його створення не завжди відповідає сучасним вимогам за матеріало- та енергоємністю.

Аналіз останніх досліджень i публікацій. Питанням, що пов'язані 3 процесом формоутворення гвинтових заготовок присвячені роботи ряду авторів [1, 2. 3], однак особливості формоутворення гофрованих гвинтових заготовок розглянуті недостатньо.

Мета статті. Розробка технологічного спорядження для ефективного технологічного процесу формоутворення гвинтових гофрованих заготовок, який забезпечив би точність, економічність та підвищення продуктивності праці.

Матеріал досліджень. Пристрій для виготовлення гофрованих гвинтових заготовок циліндричними формуючими елементами зображено на рис. 1. Його виконано у вигляді ступінчастої оправи 1 із торцевим виступом 2, який виконано 3 кроком рівним товщині заготовки 3 з гофрами. Ступінчата оправа має осьовий паз 4 для закріплення кінця заготовки $\mathrm{i}$ привід обертання від шпинделя верстату. Притискування заготовки 3 до торцевого виступу 2 ступінчатої оправи 1 зверху здійснюється притискним роликом 5 з гофрованими поверхнями 6. Притискний ролик центральним отвором встановлений на вісь 7 , яка паралельна осі ступінчатої оправи 1, 3 можливістю вільного обертання. 3 правої сторони ступінчата оправа 1 переходить в менший діаметр 8 на який навивається гвинтова гофрована заготовка 3 , а вільний кінець ступінчатої оправи підтискується піноллю задньої бабки 9. Знизу під меншим діаметром 8 розміщений формуючий ролик 10 , який виконано ступінчатим, верхня його ступиця виконана 3 гофрами по всій висоті, які є аналогічними з гофрами притискного ролика 5. Формуючий ролик 103 можливістю вільного обертання встановлено на осі яка перпендикулярна до осі ступінчатої оправи 1 і лежить 3 нею в одній вертикальній площині, він торцевою поверхнею 11 більшої ступиці $\epsilon$ в контакті з ребром заготовки і притискує ії до торцевого виступу 2 ступінчатої оправи 1 знизу. Горизонтальне притискування заготовки 3 до ступінчатої оправи 1 здійснюється торцевою гофрованою поверхнею меншої ступиці формуючого ролика 10. Останній встановлено на підшипниковій втулці 12, яка вільно обертається на осі 13 закріпленій в кронштейні 14, який встановлений на супорті верстата 15 з можливістю переміщення паралельно осі ступінчатої оправи 3 подачею на оберт рівною товщині заготовки з гофрами. Для підвищення жорсткості пристрою формуючий ролик 10 спирається на кронштейн 14 через прокладку 16 і підшипник 17. Він закритий кожухом 18 для захисту механізму від забруднення. 
Технологічний процес навивання гофрованих гвинтових заготовок здійснюється наступним чином.

Формуючий ролик 10 і притискний ролик 5 відводяться 3 зони формоутворення. Кінець заготовки 3 згинається під кутом $90^{\circ}$ і вводиться в паз 4 де фіксується відомими способами. Після чого формуючий ролик 10 підтискує заготовку 3 до торцевого виступу 2 і меншого діаметра 8 і здійснюється навивання одного витка. Після цього притискний ролик 5 підводять до заготовки 3, включають верстат і здійснюють процес навивання гофрованих заготовок. Після завершення навивання гофрованої гвинтової заготовки 3 верстат зупиняють. Відводять піноль задньої бабки 9 вправо, а притискний 5 і формуючий 10 ролики теж відводять 3 зони формоутворення, відпускають кінець заготовки і знімають ії з оправки.

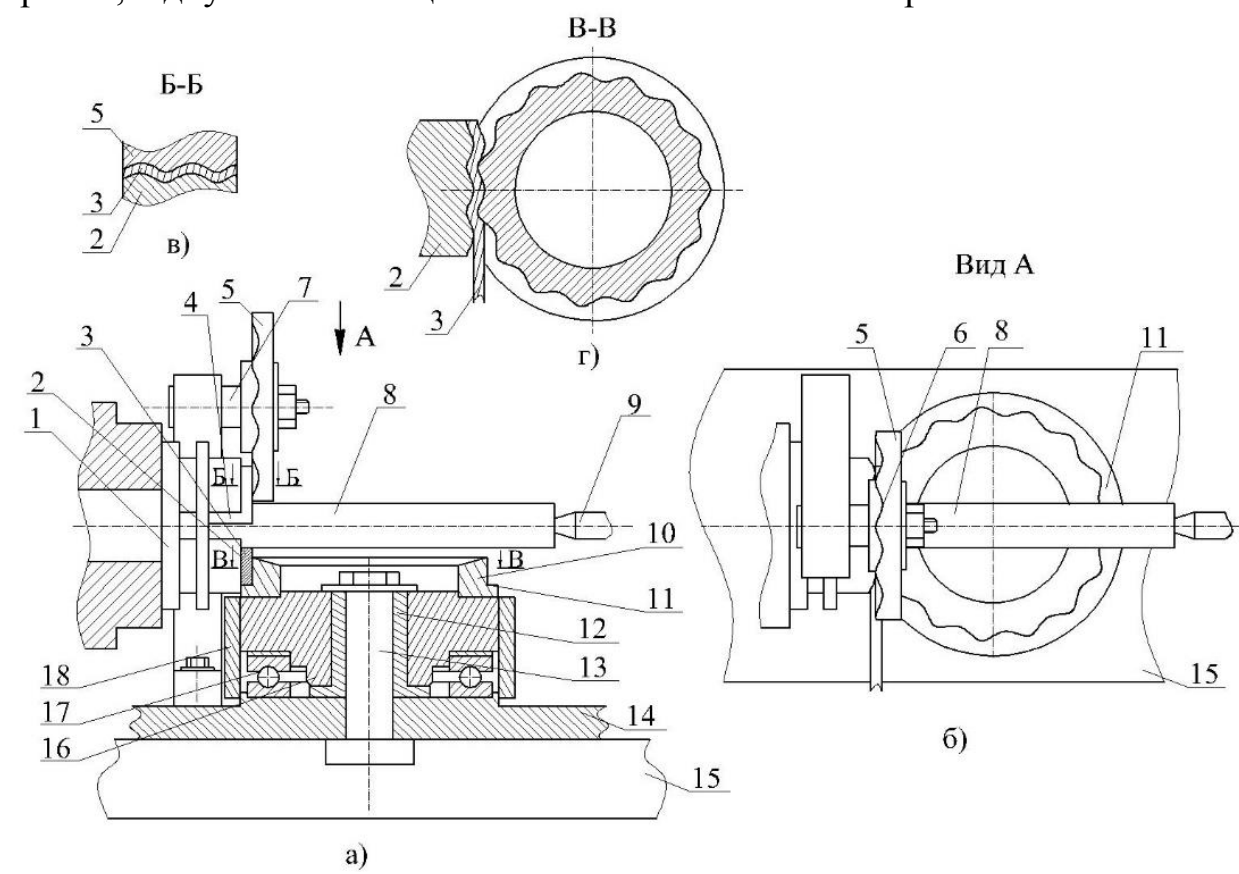

Рис. 1. Пристрій для виготовлення гвинтових гофрованих заготовок циліндричними формуючими елементами:

а) загальний вигляд; б) вид А; в) розріз Б-Б; г) розріз В-В

Навивання наступної заготовки здійснюється аналогічно.

До переваг запропонованого пристрою відноситься розширення технологічних можливостей і можливість навивання гофрованих гвинтових заготовок різних типорозмірів.

Пристрій для виготовлення гофрованих гвинтових заготовок конічними формуючими елементами зображено на рис. 2. Його виконано у вигляді опори 1 , на яку зверху встановлена формувальна основа 2, яка виконана круглої форми, на ії верхній торцевій поверхні виконане зубчасте конічне зачеплення 3. Останнє взаємодіє з відповідним конічним зачепленням формувального валка 4 через товщину заготовки 5, яка формується. Вісь формувального валка 4 виконана під кутом $\alpha$ до горизонту рівним величині кута нахилу гофри до площини гвинтової заготовки. Формувальна основа і формувальний валок мають приводи, які не показані на кресленні і обертаються згідно вказаних стрілок. Крім цього формувальна основа 2 встановлена на опору 13 можливістю кругового обертання через тіла кочення 6. Ліва опора 7 формувального валка 4 встановлена в ексцентричну втулку 8 з ексцентриситетом (максимальна різниця товщин втулки в діаметральних напрямках) рівним максимально допустимій різниці товщин заготовок $\mathrm{t}_{1}<\mathrm{t}_{2} 3$ зовнішніми шліцами, яка через шліцеве з'єднання $\epsilon$ у взаємодії 3 кронштейном 9, який жорстко закріплений до опори 1. Права опора 10 формувального валка 4 встановлена в отвір 11 в круглій головці стяжного болта 12, який жорстко встановлений в центральний отвір опори 1. На чотирьох сторонах головки стяжного болта 12 виконані отвори під праву опору 10 на різній висоті з врахуванням товщини заготовки при формуванні гофр. Стяжний болт 12 в отворі формувальної основи в разі потреби можна фіксувати від можливого провертання відомими способами за допомогою шпоночного або шліцевого з'єднань 3 затягуванням гайки 13 , а висоту головки стяжного болта 12 можна регулювати встановленням шайб 14 необхідної товщини. 


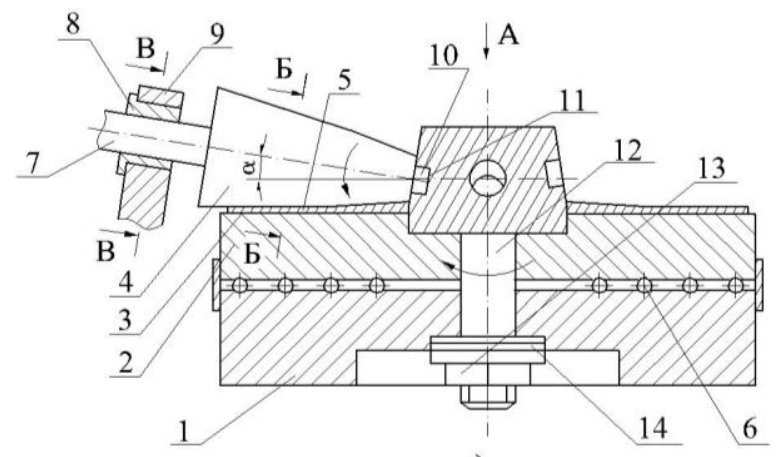

a)

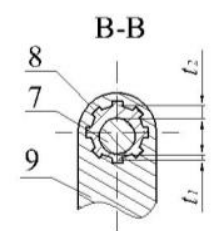

г)

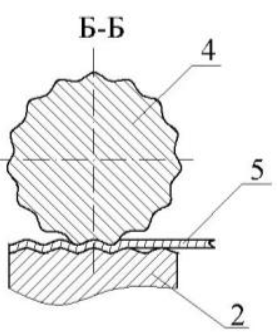

в)

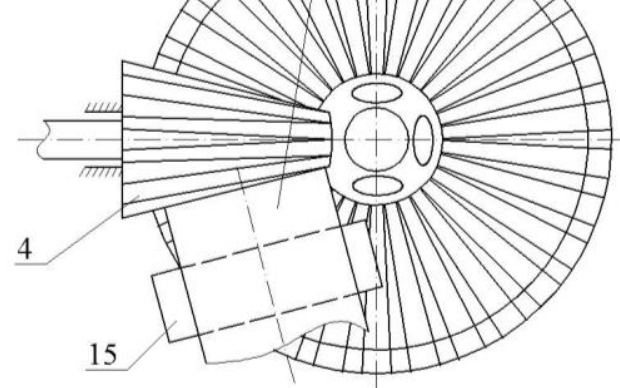

б)

Рис. 2. Пристрій для виготовлення гофрованих гвинтових заготовок конічними формуючими елементами:

а) загальний вигляд; б) вид А; в) розріз Б-Б; г) розріз В-В

Регулювання правильної подачі полоси 5 в зону формоутворення гофрованої гвинтової заготовки здійснюється за допомогою механізму подачі 15 який можна регулювати як для різних параметрів заготовки так і для правильного направлення в зону формоутворення.

Робота пристрою для виготовлення гофрованих гвинтових заготовок здійснюється після настроювання пристрою на роботу з заготовками певної ширини і товщини. Для цього механізм подачі встановлюють з врахуванням цих параметрів, а регулювання величини зазору між формувальним валком і формувальною основою здійснюють встановленням правої опори формувального валка у відповідний отвір з чотирьох можливих.

Після цих підготовчих операцій вмикають привід і формувальна основа 2 і формувальний валок 4 обертаються у відповідному напрямку. Заготовку 5 через механізм подачі 15 подають в зону їх зачеплення. При цьому при формуванні гофр заготовка 5 скручується у гвинтову спіраль 3 кроком більшим максимального діаметра формувального валка 4. Після завершення навивання партії однотипних гвинтових гофрованих заготовок пристрій зупиняють, і в разі потреби переобладнують його на виготовлення нового типу заготовок.

До переваг пристрою відносять простоту конструкції і високу продуктивність праці.

Розглянемо процес утворення гофрованих заготовок прямозубими колесами (рис. 3).

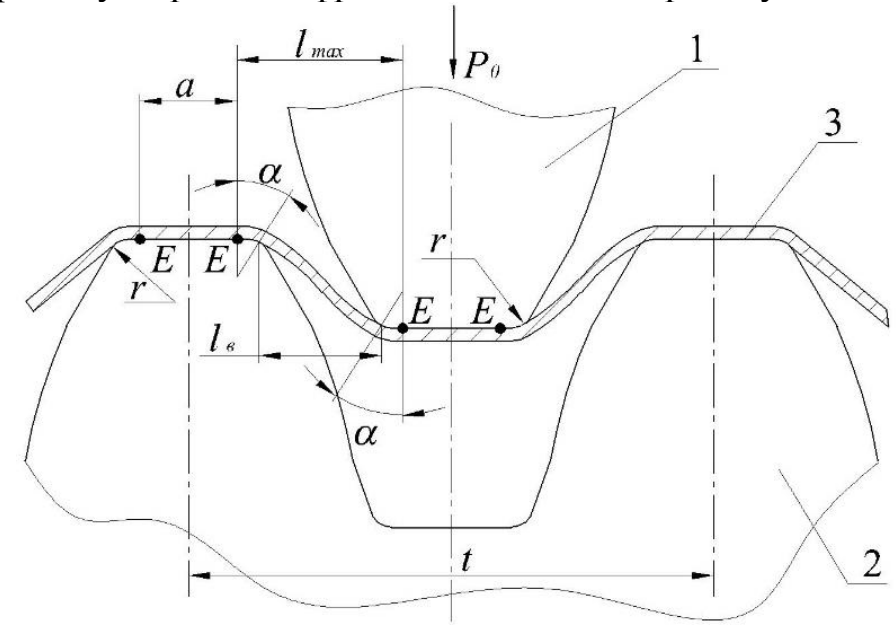

Рис. 3. Розрахункова схема гофроутворення

1 - зуб верхнього колеса; 2 - зуб нижнього колеса; 3 - стрічка 
Визначимо зусилля $P_{0}$, яке необхідне для гнуття заготовки у вигляді стрічки між двома прямозубими колесами.

Розглянемо цей випадок, як балку, що загинається навколо робочих кромок зубів в чотирьох точках $E$ з радіусом згину $r$. [3]:

Із умови рівності згинних моментів зовнішніх і внутрішніх сил можна вивести рівняння

$$
M=P_{0} \cdot l_{B}=4 W\left(1,5+\varepsilon_{b}\right) \sigma_{b}=\frac{4 b s^{2}}{6}\left(1,5+\varepsilon_{b}\right) \sigma_{b},
$$

де $W$ - момент опору гнуттю;

$\varepsilon_{b}$ - відносне видовження даного матеріалу в момент початку утворення шийки;

$\sigma_{b}$ - тимчасовий опір розриву;

$b$ - ширина стрічки;

$S$ - товщина стрічки;

$l_{6}$ - величина плеча, яке змінюється по мірі опускання зуба у впадину, визначається із геометричних співвідношень.

$$
l_{B}=\frac{t}{2}-a-2 r \cdot \sin \alpha,
$$

де $t$ - крок зубів;

a - величина прямолінійної ділянки зуба;

$r$ - радіус заокруглення при вершині зубів;

$\alpha$ - кут гнуття, що утворюється в результаті переміщення крайньої точки контакту матеріалу із заокругленнями зубів.

Тоді:

$$
P_{0}=\frac{4 b S_{2}\left(1,5+\varepsilon_{b}\right) \sigma_{b}}{6\left(\frac{t}{2}-a-2 r \cdot \sin \alpha\right)} .
$$

Оскільки, крім зусилля, потрібного для гнуття, доводиться також долати силу тертя між поверхнею деталі і робочими кромками зубів при переміщенні заготовки, то дійсне зусилля $P$ буде завжди більшим на величину сили тертя $\boldsymbol{F}_{m p}$, яку при коефіцієнті тертя $\mu=0,3$ можна прийняти з деяким запасом:

$$
P=P_{0}+F_{m p}=1,3 P_{0} .
$$

Найменше зусилля гофроутворення буде при горизонтальному положенні стрічки на початку гнуття при $l_{\max }=\frac{t}{2}-a$, найбільше в кінці, коли $\alpha \rightarrow 90$. Для цього випадку

$$
P=1,3 F_{0}=\frac{1,3 \cdot 4 b S_{2}\left(1,5+\varepsilon_{b}\right) \sigma_{b}}{6\left(\frac{t}{2}-a-2 r\right)} .
$$

Аналізуючи процес формоутворення гофр між двома конічними зубчастими колесами, встановлено, що згідно (2) плече $l_{6}$ буде змінюватися рівномірно вздовж всієї ширини заготовки.

Звідси, сила гофроутворення на більшому радіусі гнуття буде меншою ніж на меншому радіусі гнуття.

Крім цього, внаслідок виникнення різниці напружень по ширині стрічки, утворюється гофрована спіралевидна поверхня.

Зусилля, що необхідне для гофрування двома конічними зубчастими колесами $P_{c p}$, визначаємо як середнє значення зусиль гнуття по більшому і по меншому радіусах 3 врахуванням сили тертя на переміщення заготовки.

$$
P_{c p}=1,3 \frac{P_{3}+P_{B}}{2} .
$$

Згідно (3) 


$$
\begin{aligned}
& P_{3}=\frac{4 b S_{2}\left(1,5+\varepsilon_{b}\right) \sigma_{b}}{6\left(\frac{t}{2}-a_{3}-2 r_{3} \cdot \sin \alpha\right)} ; \\
& P_{B}=\frac{4 b S_{2}\left(1,5+\varepsilon_{b}\right) \sigma_{b}}{6\left(\frac{t_{B}}{2}-a_{B}-2 r_{B} \cdot \sin \alpha\right)},
\end{aligned}
$$

де $P_{3}$ і $P_{B}$ - відповідно зусилля гофроутворення по більшому і по меншому радіусах.

$t_{3}$ і $t_{B}$ - відповідно крок зубів на зовнішньому і на внутрішньому діаметрах конічних зубчастих коліс;

$a_{3}$ і $a_{B}$ - відповідно величини прямолінійних ділянок зубів на зовнішньому і на внутрішньому діаметрах конічних зубчастих коліс;

$r_{3}$ і $r_{B}$ - відповідно радіуси заокруглення при вершинах зубів на зовнішньому і на внутрішньому діаметрах конічних зубчастих коліс.

Крім вищезгаданих способів утворення гофр можна використовувати прямі і конічні колеса із зубами, що відповідають профілю утворюваної гофри. Перевагою цього методу над попередніми $\epsilon$ те, що утворюються криволінійні ділянки при гнутті.

Зусилля гофроутворення колесами із спеціальними зубами $P_{0}$ визначаємо аналогічно до зусиль при використанні модульних зубчастих коліс. Змінюється лише значення плеча $l_{b}$ :

$$
l_{6}=\frac{t}{2}-2 r_{3} \sin \alpha .
$$

Для прямозубих коліс:

$$
P_{0 n p}=\frac{1,3 \cdot 4 b S_{2}\left(1,5+\varepsilon_{b}\right) \sigma_{b}}{6\left(\frac{t}{2}-2 r_{3} \cdot \sin \alpha\right)}
$$

Для конічних коліс:

$$
P_{c p}=1,3 \frac{F_{3}+F_{B}}{2} . \quad P_{3}=\frac{4 b S_{2}\left(1,5+\varepsilon_{b}\right) \sigma_{b}}{6\left(\frac{t_{3}}{2}-2 r_{33} \cdot \sin \alpha\right)} . \quad P_{B}=\frac{4 b S 2\left(1,5+\varepsilon_{b}\right) \sigma_{b}}{6\left(\frac{t_{B}}{2}-2 r_{3 B} \cdot \sin \alpha\right)} .
$$

На основі рівнянь (10-11) побудовано графіки (рис. 4) сили гофроутворення в залежності від ширини стрічки.

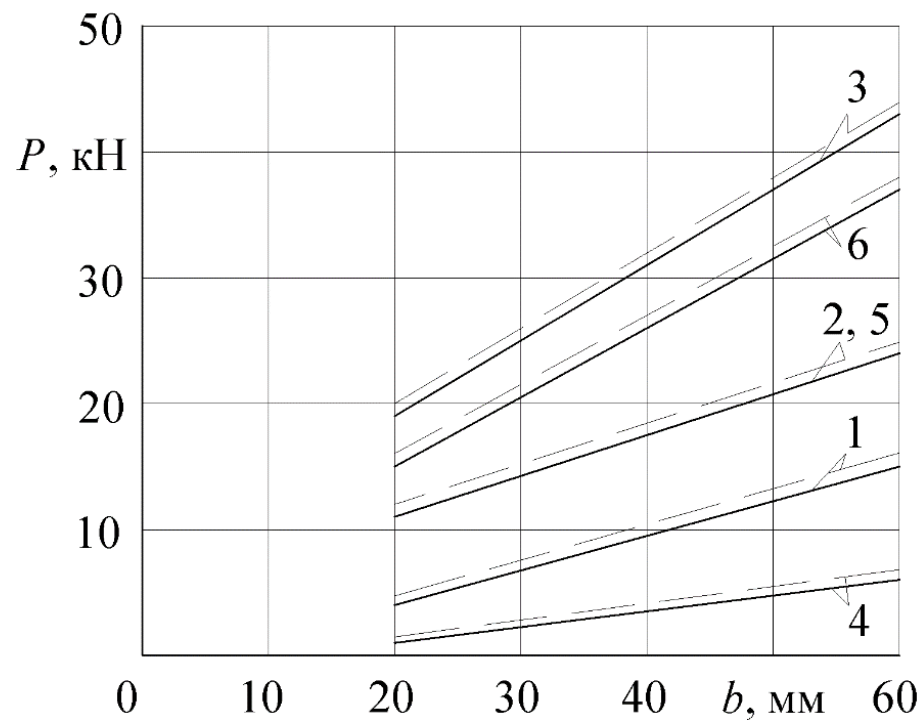

Рис. 4. Залежність сили гофроутворення від ширини стрічки $\mathrm{t}=20 \mathrm{mm;} \alpha=70^{\circ}$ :

сталь 08кп - 1) $\mathrm{S}=1$ мм; 2) $\mathrm{S}=1$,5мм; 3) $\mathrm{S}=2$ мм; алюміній Д16М - 4) $\mathrm{S}=1$ мм; 5) $\mathrm{S}=2 \mathrm{Mм}$; 6) $\mathrm{S}=2,5 \mathrm{mм}$;

прямі колеса_ конічні колеса 
Висновки. Під час проведення досліджень з удосконалення технологічного процесу формоутворення гвинтових гофрованих заготовок було отримано наступні основні результати:

-розроблено пристрій для виготовлення гофрованих гвинтових заготовок циліндричними формуючими елементами. До переваг даного пристрою відноситься розширення технологічних можливостей і можливість навивання гофрованих гвинтових заготовок різних типорозмірів;

-розроблено пристрій для виготовлення гофрованих гвинтових заготовок конічними формуючими елементами. До переваг пристрою відносять простоту конструкції і високу продуктивність праці;

-отримано вирази для знаходження зусилля гофроутворення для різних способів отримання гофр.

\section{Інформаційні джерела:}

1. Гевко Б.М., Ляшук О.Л., Гевко І.Б., Драган А.П., Новосад І.Я. Технологічні основи формоутворення спеціальних профільних гвинтових деталей. - Тернопіль: СМП “Тайп. - 2008. $367 \mathrm{c}$.

2. Гевко Б.М. Технологические основы выбора конструктивных параметров шнеков // Изв. вузов. Машиностроение, 1982. - № 5. - С. 148 - 151.

3. Ляшук О.Л. Технологічне забезпечення виготовлення деталей типу “тіл обертання" 3 профільного прокату. Ареф. дис. к.т.н. 05.02.08. Технологія машинобудування, Тернопіль 2006p., 20c.

\section{Драган А.П.}

ОП НУБиП Украины «Бережанский агротехнический институт»

\section{ТЕХНОЛОГИЧЕСКОЕ СНАРЯЖЕНИЕ ДЛЯ НАВИВКИ ВИНТОВЫХ ГОФРИРОВАННЫХ ЗАГОТОВОК С ЗАДАННЫМ ПРОФИЛЕМ}

В данной статье приведены образиы технологической оснастки для изготовления винтовых гофрированных заготовок с заданным профилем гофр. В частности устройство для изготовления гофрированных винтовых заготовок иилиндрическими формируюшими элементами и устройство для изготовления гофрированных винтовых заготовок коническими формируюшими элементами. Рассмотрены теоретические основы процесса формообразования гофрированных винтовых заготовок Определены усилия, которое необходимо для гибки заготовки в виде ленты между двумя прямозубыми колесами, косозубыми колесами, и колесами специального профиля. На основе полученных уравнений построены графики зависимости силь гофрообразованияя от ширины ленты.

Ключевые слова: винтовая гофрированная заготовка, усилия формообразования.

\section{Drahan A.P.}

Separated Subdivision of National University of Life and Environmental Sciences of Ukraine «Berezhany agrotechnical institute»

\section{TECHNOLOGICAL EQUIPMENT FOR WRAPPING CORRUGATED SCREW BLOCKS WITH A GIVEN PROFILE}

This article presents samples of technological equipment for the manufacture of corrugated screw blanks with a given corrugation profile. in particular a device for the manufacture of corrugated screw blanks with straight-toothed forming elements and a device for the manufacture of corrugated screw blanks with helical forming elements. The theoretical bases of the process of forming corrugated screw blanks are considered. The effort required for bending the workpiece in the form of a tape between two spur gears, helical gears, and wheels of special profile is determined. Based on the obtained equations, graphs of the dependence of the corrugation force on the width of the tape are constructed.

Key words: Screw corrugated blank, shaping efforts. 